\title{
Breastfeeding Promotion and Baby-Friendly Health Facilities in Turkey: A Systematic Approach to Scale up the Program
}

\section{Türkiye'de Emzirmenin Teșviki ve Bebek Dostu Sağlık Kurulușları: Programı Geliştirmek İçin Sistematik Bir Yaklaşım}

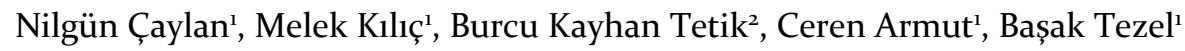 \\ ${ }^{1}$ Ministry of Health, Public Health General Directorate, Department of Child and Adolescent Health, \\ Ankara \\ 2İnönü University Faculty of Medicine, Department of Family Medicine, Malatya
}

\begin{abstract}
Objectives: In Turkey, Breastfeeding Promotion and Baby-Friendly Health Facilities Program (BFHF) was launched in 1991 with the collaboration of the Ministry of Health $(\mathrm{MoH})$ and United Nations International Children's Emergency Fund (UNICEF). Since 2002, the program has been extended from hospitals to the primary health care services and the community level. This paper aims to present the current status of BFHF and development of new strategies to revitalize the program and thus, to contribute to the progress.

Materials and Methods: All information about health facilities and provinces was collected from the database of the Child and Adolescent Health Department. Discussions about Initiative with stakeholder institutions and baby-friendly advocates took place in the National Breastfeeding Committee Meeting and in Annual Breastfeeding Symposium. Then a SWOT (strengths, weaknesses, opportunities, threats) analysis of the Program was performed by the working group. Using this analysis results, new strategies and course of action were identified.

Results: The current number of baby-friendly hospitals has reached a total of $1051(69.42 \%$ of all hospitals). Of those, 46 were maternity hospitals, which were $93.50 \%$ approved as baby-friendly at the end of 2017. Between 2008 and 2017, 120 (\%11.42) of those pre-certified hospitals were reassessed. Between 2002 and 2013, all 81 provinces have been designated Baby-Friendly Provinces. Since 2008, 61 of the 81 provinces have been designated Golden Baby-Friendly Provinces and 95\% of Family Medicine Units have been certified as baby-friendly. According to the SWOT analysis result, the main strength of the program was strong recognition and support of the BFHF by the government. The difficulties in maintaining of baby-friendly standards in health facilities and inadequate reassessment of pre-certified facilities were determined as the main weaknesses of the BFHF by the working group.

Conclusion: To protect, promote and support breastfeeding effectively and to reach the national and global breastfeeding goals, interventions should be planned in a combination of settings by concurrently involving health policies, health systems, home, family and the community.

Key Words: Baby-Friendly Hospital Initiative, Baby-Friendly Health Facilities, breastfeeding promotion, breastfeeding rates, complementary feeding, International Code of Marketing of Breastmilk Substitutes
\end{abstract}

$\ddot{O} \mathbf{z}$

Amaç: Türkiye'de Emzirmenin Teșviki ve Bebek Dostu Sağlık Kuruluşları Programı (BDSK), 1991 yılında Sağlık Bakanlığı ve Birleșmiș Milletler Çocuklara Yardım Fonu (UNICEF) işbirliği ile başlatılmıştır. 2002'den beri Program hastanelerden birinci basamak sağllk hizmetlerine ve toplum düzeyine ilerlemiștir. Bu yazıda, mevcut durumu değerlendirmek ve Programı canlandırmak için geliștirilen yeni stratejileri sunmak ve böylece Programın ilerlemesine katkı sağlamak hedeflenmektedir. Materyal ve Metot: Sağlık kuruluşları ve illere ait tüm veriler, Çocuk ve Ergen Sağlığı Daire Bașkanlığı'nın veri tabanından alınmıștır. Paydaș kurumlarla ve tüm bebek dostu savunucuları ile Ulusal Emzirme Komitesi Toplantısında ve Ulusal Emzirme Sempozyumunda Program hakkında tartışmalar gerçekleștirilmiş ve ardından çalışma grubu tarafından Programın SWOT (güçlü yönler, zayıf yönler, fırsatlar, tehditler) analizi yapılmıștır. Sonrasında bu analiz sonuçları kullanılarak yeni stratejiler ve yol haritası belirlenmiștir.

Bulgular: Bebek dostu hastanelerin güncel sayısı 2017 yılı sonu itibariyle 1051'e (tüm hastanelerin \%69,42'si) ulaşmıștır. Bu hastanelerin 46’sı kadın doğum hastanesi statüsündedir ve \%93,50'si 2017 yılı 
Breastfeeding Promotion and Baby-Friendly Health Facilities in Turkey: A Systematic Approach to Scale up the Program

sonu itibariyle bebek dostu olarak onaylanmıștır. 2008 ve 2017 yılları arasında önceden bebek dostu unvanı almıș olan hastanelerin 120'si $(\% 11,42)$ yeniden değerlendirilmiștir. 2002 ve 2013 yılları arasında 81 ilin tamamı bebek dostu unvanı almıștır. 2008 yılından itibaren 81 ilin 6ı'i Bebek Dostu İl unvanını Altın Bebek Dostu İl olarak geliștirmiș ve Aile Hekimliği Birimlerinin \%95’i bebek dostu unvanı almıștır. SWOT analizi sonuçlarına göre programın en güçlü yönü BDSK'nın devlet tarafından güçlü bir şekilde tanınması ve desteklenmesi olarak belirlenmiștir. Sağlık kuruluşlarında bebek dostu standartların sürdürülmesinde yaşanan güçlükler ve bebek dostu unvanı alan hastanelerin yeterince yeniden değerlendirilememesi çalışma grubu tarafından programın en zayıf yönleri olarak değerlendirilmiștir.

Sonuç: Emzirmeyi etkili bir șekilde korumak, teșvik etmek ve desteklemek, ulusal ve küresel emzirme hedeflerine erişmek için girişimlerin sağlık politikaları, sağlık sistemleri, ev, aile, toplum gibi bir dizi ortamın kombinasyonunu kapsayacak şekilde planlanması gereklidir.

Anahtar Kelimeler: Bebek Dostu Hastaneler Girişimi, Bebek Dostu Sağlık Kuruluşları, emzirmenin teșviki, emzirme oranları, tamamlayıcı beslenme, Anne Sütü Muadillerinin Pazarlanması ile İlgili Uluslararası Yasa

\section{Yazıșma Adresi / Correspondence:}

Dr. Nilgün Çaylan

Sağglık Bakanlığı, Halk Sağlığı Genel Müdürlüğü, Çocuk ve Ergen Sağlığı Daire Başkanlığı, Ankara

e-mail: nilgun.caylan@gmail.com

Date of submission: 07.07.2018

Date of admission: 01.03.2019

\section{Introduction}

Breast milk is known as the best nutrition option for the growth and development of infants. The short- and long-term benefits of breastfeeding for children, mothers, families, and societies are well documented. ${ }^{1-4}$ Optimal breastfeeding practices are fundamental for child survival, nutrition and early childhood development.3,4 The Lives Saved Tool estimated that 823 ooo annual deaths in children younger than 5 years could have been prevented in low and middle income countries in 2015 if breastfeeding had been increased to near global levels. ${ }^{4}$

Historically, after the Innocenti Declaration was signed by 30 countries in 1990, the protection, promotion and support of breastfeeding became a global health priority. ${ }^{5}$ The Baby-Friendly Hospital Initiative (BFHI) was designed in the early 1990 os by the World Health Organization (WHO) and United Nations International Children's Emergency Fund (UNICEF) as a global campaign in response to the Innocenti Declaration. Adopting the Ten Steps to Successful Breastfeeding and complying with the International Code of Marketing of Breastmilk Substitutes (Code) have been two essential components of the BFHI.6,7 In 2002, WHO and UNICEF approved the "Global Strategy for Infant and Young Child Feeding". ${ }^{8}$ The initiation of breastfeeding within one hour after birth, exclusive breastfeeding (EBF) for 6 months, and nutritionally adequate and safe complementary feeding starting from the age of 6 months with continued breastfeeding up to 2 years of age or beyond are the key recommendations of this strategy. ${ }^{9}$ In 2012, the World Health Assembly approved an implementation plan on maternal, infant and young child nutrition, specifying six global nutrition targets by 2025, one of which is to increase the rate of EBF in the first 6 months up to at least $50 \%{ }^{10}$

In Turkey, Breastfeeding Promotion and Baby-Friendly Health Facilities Program (BFHF) was launched in 1991 with the collaboration of the Ministry of Health (MoH) and UNICEF immediately following the world breastfeeding developments. Since 2002, 
Breastfeeding Promotion and Baby-Friendly Health Facilities in Turkey: A Systematic Approach to Scale up the Program

the program has been extended from hospitals to the primary health care services and the community level. ${ }^{11}$ This paper aims to present the current status of BFHF and development of new strategies to revitalizing the program and thus, to contribute to the progress.

\section{Health Care System in Turkey}

In Turkey, the National Health System is structured into three levels: primary, secondary and tertiary care. ${ }^{12}$ Primary health care services are carried out in Family Health Centers (FHCs), which consist of Family Medicine Units (FMUs) and Community Health Centers (CHCs) that are staffed by family doctors, family physician specialists, primary care physicians, nurses, midwives and other administrative staff. FHCs and CHCs are under the supervision of Provincial Health Directorates (PHD) in all 81 provinces, which are responsible for the planning and provision of primary health care services at the provincial level and accountable to the MoH. ${ }^{12}$ University hospitals, training and research hospitals/teaching hospitals, branch hospitals, and some maternity clinics are the major providers of tertiary care. All remaining hospitals are secondary care hospitals. In Turkey, approximately $98 \%$ of all deliveries occur in the maternity clinics of hospitals. ${ }^{13}$

\section{The History of the Breastfeeding Promotion and Baby-Friendly Health Facilities in Turkey}

In Turkey, BFHF was launched in 1991 in cooperation with UNICEF-Turkey and the $\mathrm{MoH}$. The National Breastfeeding Committee (NBFC) and Scientific Committee were formed and coordinators assigned. The $\mathrm{MoH}$ is the national coordinator of the program, and the Child and Adolescent Health Department (CAHD) is responsible for conducting this program on behalf of the $\mathrm{MoH}$. Structure of the program coordination is shown in Figure 1. As the national coordinator of the program, the $\mathrm{MoH}$ is responsible for developing programs, policies and legislation, coordinating the certification and re-evaluation of BFHF processes of facilities, and overseeing the activities of the enforcement units with the help of NBFC and Scientific Committee members. ${ }^{11}$

In 2002, to extend breastfeeding support to the community level, the Scientific Committee proposed an expansion of the BFHF to primary health care services. As a result, Baby-Friendly Primary Health Care Program was started and subsequently, the Baby-Friendly Province Program was launched within the same year. In 2008, the Baby-Friendly Province Program was enhanced as the Golden Baby-Friendly Province. Lastly, to support breastfeeding in neonatal intensive care units (NICU), Baby-Friendly Neonatal Intensive Care Unit Program was launched in 2012."

While supporting breastfeeding in health facilities, mother-to-mother support groups (MMSGs) began to flourish to ensure the continuation of breastfeeding after hospital discharge. First, CHC staff received breastfeeding training, and the trained staff then arranged training activities for volunteer leader mothers in the community. These mothers enabled the formation of breastfeeding support groups, who organize group meetings in health facilities or other convenient places. Pregnancy classes have developed positive initiatives that have been introduced as part of prenatal care in CHCs. The curriculum of these initiatives includes breastfeeding training for pregnant women, which represents Step 3. (Table 1$){ }^{6}$ 
Breastfeeding Promotion and Baby-Friendly Health Facilities in Turkey: A Systematic Approach to Scale up the Program

National goals for infant feeding have been set by the $\mathrm{MoH}$, and promotion, protection and support of breastfeeding are among the national public health priorities. The $\mathrm{MoH}$ strategic plan for 2013-2017 includes articles on infant feeding, which is compatible with the WHO global recommendations. ${ }^{14}$ Although Turkey has enacted legislation or other legal measures encompassing a few provisions of the Code, it has not been made into law yet. 15

\section{Becoming Baby-Friendly}

In Turkey, the BFHF certification process is coordinated locally by PHD in collaboration with the CAHD. Baby-friendly certification process of hospitals, maternity hospitals and NICUs is shown in Figure 2. During the external assessment of the facility, National Evaluation Team (NET) globally assesses the degree to which a hospital has achieved to measurable criteria, The Ten Steps to Successful Breastfeeding using standard evaluation forms adapted from revised materials in 2009. ${ }^{11} 16$ NET also interviews staff who work with pregnant women, mothers, or babies and interviews pregnant women and mothers about the care they received in the facility. The facility must earn at least 80 points on a scale of 100 (Steps 1, 2, and 3 are mandatory) (Table 1). The certification process for the Baby-Friendly Primary Health Care Program is carried out locally by PHD on the basis of nine steps. Additionally, to be a Baby-Friendly Province or a Golden Baby-Friendly Province, PHD organizes and follows activities locally and prepares the province's application file. The NBFC evaluates the files, and a Baby-Friendly Province or Golden Baby-Friendly Province certificate is awarded if the province's application file is found to be sufficient. This certificate is valid for 5 years. The criteria for the Baby-Friendly Province Program and the Golden Baby-Friendly Province are presented in Table $2 .{ }^{11}$

\section{The development of breastfeeding indicators in Turkey}

Data on breastfeeding prevalence were obtained from the Demographic and Health Surveys (DHS), which is carried out every 5 years by the Hacettepe University Institute of Population Studies. ${ }^{17}$ The data collection method was established as interviewing a Turkish population determined via a weighted, multi-stage, stratified cluster sampling method. Results from the DHS demonstrate that the median breastfeeding duration increased from 12 months in 1993 to 16.90 months in 2013. The EBF rates under six months increased from $10.40 \%$ in 1993 to $41.60 \%$ in 2008 , but a decrease was observed in 2013, and the ratio was noted as $30.10 \%$ (Table 3 ). ${ }^{17}$ Breastfeeding indicators from 1993 to 2013 are presented in Table $3 \cdot{ }^{17}$ Infant feeding status under 6 months according to DHS 2013 is also showed in Figure $4 .{ }^{17}$

According to the Figure 4, although in the o-1 months of life, exclusive breastfeeding rate is $57.90 \%$, this rate decreases rapidly with the age of infant, dropping to $9.50 \%$ for infants who are 4-5 months old. The figure 4 also shows that 1.50 percent of infants in 2-3 months old and 29.30 percent of infants in 4-5 months old are given complementary foods. ${ }^{17}$

\section{Materials and Methods}

All information about health facilities and provinces was collected from the database of the CAHD. Data were reviewed and statistical analyses and assessments were 
Breastfeeding Promotion and Baby-Friendly Health Facilities in Turkey: A Systematic Approach to Scale up the Program

performed by a working group. Microsoft Office Excel 2007 software was used for data processing.

Discussions regarding revitalization of the Initiative with stakeholder institutions and baby-friendly advocates took place in NBFC Meeting and in Annual Breastfeeding Symposium organizing by non-governmental organization (NGO) and $\mathrm{MoH}$ collaboration. Then a SWOT (strengths, weaknesses, opportunities, threats) analysis was performed by the same working group. Using this analysis results, new strategies and course of actions were identified. This study was approved by the Institutional Review Board and permissions were received for the use, analysis and share of data.

\section{Results}

\section{Hospitals/Maternity Hospitals}

The current number of baby-friendly hospitals has reached a total of 1051 (69.42\% of all hospitals). Of those, 46 were maternity hospitals, which were $93.50 \%$ approved as baby-friendly at the end of 2017. Between 2008 and 2017, 120 (\%11.42) of those precertified hospitals were reassessed externally by the NET. Approximately $92 \%$ of all births in Turkey occur in baby-friendly hospitals.

Thirty-eight NICUs have been certified as baby-friendly since 2012, and twenty-three NICUs have completed arrangements and preliminary assessments, and they are in the certification process.

\section{Baby-Friendly Province/Golden Baby-Friendly Province}

Between 2002 and 2013, all 81 provinces have gradually been evaluated by the NBFC and have been designated Baby-Friendly Provinces. Since 2008, 61 of the 81 provinces enhanced their Baby-Friendly Province certificate and have been designated Golden Baby-Friendly Provinces. The status of Baby-Friendly Province and Golden BabyFriendly Province Programs in 2017 is shown in Figure 3.

\section{Baby-Friendly Family Medicine Units and other facilities}

As of 2017, 95\% of FMUs have been certified as baby-friendly by the PHDs and MMSGs have been established in 33 provinces.

SWOT analysis results and proposed new strategies of the BFHF Program are showed in Table 4.

\section{Discussion}

This paper presents the current status of BFHF practices, implementation strategies, breastfeeding indicators and a detailed analysis of the BFHF-Turkey for determination of new strategies. The $\mathrm{MoH}$ assume the leading role for the protection, promotion and supporting breastfeeding in Turkey. The BFHF administration mode of Turkey is a government-directed implementation model and closely resembles the first described model in the WHO revised materials. ${ }^{18}$ According to the SWOT analysis result, the main strength of the program was strong recognition and support of the BFHF by the government. This case is compatible with the results of an integrative review assessing barriers, facilitators and recommendations with the Baby-Friendly Initiative by Semenic et al. ${ }^{19}$ Although a strong political will, advocacy and leadership by the $\mathrm{MoH}$ offers multiple opportunities for managing, funding and sustaining the program, the 
Breastfeeding Promotion and Baby-Friendly Health Facilities in Turkey: A Systematic Approach to Scale up the Program

major disadvantages of this implementation model include a multitude of bureaucratic procedures, slow progress, and inadequate control over the quality of activities (Table 4)..$^{18}$

Once a health facility has been designed baby-friendly, sustainability of baby-friendly standards has great importance. Monitoring and reassessing the hospital's adherence to the Ten Steps regularly can help administrators and staff members to maintain standards. Reassessment should be conducted, as with the assessment, by an external team. ${ }^{16,20}$ In this study, the difficulties in maintaining of baby-friendly standards in health facilities, a vast number of health facilities and inadequate reassessment of certified facilities were determined as the main weaknesses of the BFHF by the working group. To overcome these weaknesses, working group suggested a series of strategies. To include BFHF in existing Health Service Quality Programs, Positive Performance Strategy to promote health facilities and inter-provincial external assessment strategies are the most prominent strategies established by the working group (Table 4).

Thirty years after its statement, the International Code remains key instrument for the protection of breastfeeding globally.7, 15 The implementation of the Code is critical towards reducing or eliminating all form of promotion of breast milk substitutes to pregnant women and mothers. At the same time, the Code can assure that the health system is free from commercial influences, through the elimination of free sample distribution in health care facilities, as well as other gifts and inducements to health workers. ${ }^{2}$ Although Turkey has partially implemented the International Code as a national law and aggressive advertisement and marketing strategies of the formula industry to overcome legislative regulations are common continuing problems. ${ }^{15}$ For example, advertisement strategies focusing on follow-on formula and so-called "growing up milks" can cause a cross-promotion effect for breast-milk substitutes for first six months and can undermine duration of EBF. In this study, aggressive marketing strategies and Code non-compliance practices of formula industry were detected as the main threats of the Program. To combat these threats, study group and Scientific Committee highly recommended that the Code should be enacted into law as soon as possible and fully implemented.

Breastfeeding is a traditionally common practice in Turkey, and mean breastfeeding duration has gradually improved from 1993 to $2013 .{ }^{17}$ However, some indicators, including the early initiation of breastfeeding and EBF under 6 months, are problematic and below both expected national and global targets (Table 3)..$^{10,14,21} \mathrm{In}$ Turkey, recently high caesarean delivery rates, early introduction of complementary foods especially approximately $4-6$ months and promotion of formula have been determined as prominent contributing factors for decreasing these rates. ${ }^{13,17,22}$ Moreover, some regional advisory committee reports on infant feeding are not fully aligned with the WHO global recommendation of EBF. ${ }^{23-25}$ In Turkey, these reports have been accepted by some professional associations and may have a great deal of negative influence on the daily infant and young child practices of health professionals, as in many of the WHO European Region member states. ${ }^{26}$

The global evidence consistently supports the conclusion that adherence to the Ten Steps to Successful Breastfeeding and complying with the Code have a positive impact on short and long term breastfeeding outcomes. ${ }^{27,28}$ Thereafter, community-based support appears to be key activity for long-term sustainability of the short-term 
Breastfeeding Promotion and Baby-Friendly Health Facilities in Turkey: A Systematic Approach to Scale up the Program

breastfeeding gains obtained in baby-friendly maternity facilities. 29,30 Additionally, to strengthen optimal infant feeding practices, it is important to closely link breastfeeding and complementary feeding interventions. ${ }^{30}$ Adequate support of mothers for initiating and sustaining breastfeeding and advices by trained and experienced health professionals and other support groups about the timely introduction of complementary foods are of vital importance. In Turkey, Baby-Friendly Province, Golden Baby-Friendly Province Programs, Baby-Friendly Primary Health Care Program and MMSGs were developed by adapting the BFHF to local, social and community health services in order to achieve continuum of optimal breastfeeding support. Although, these are very comprehensive and important programs carried out by the primary health care providers and local authorities, their strategies need to be revitalized with joint activities of $\mathrm{MoH}$ and other institutions to raise the breastfeeding outcomes.

The BFHF initiated by the MoH and UNICEF collaboration is a part of sound global public health intervention to protect, promote and support breastfeeding. A quarter century after the start of the program, there's still a whole lot more work to be done to improve infant and young child feeding practices. We expect that all of the new strategies identified meticulously by the working group will contribute to revitalizing the program and thus towards both promoting and maintaining breastfeeding. Finally, to protect, promote and support breastfeeding effectively and to reach the national and global breastfeeding goals, interventions should be delivered in a combination of settings by concurrently involving policies, health care systems, home, family and community. ${ }^{31}$

\section{Acknowledgment}

The authors gratefully acknowledge all members of the National Breastfeeding Committee and Scientific Committee for their significant contribution in the establishment and development of the BFHF in Turkey. Health care professionals and all volunteers advocating and supporting breastfeeding in the field was greatly appreciated.

\section{Declaration of Conflicting Interests}

All authors declare no competing interests.

\section{Funding}

The authors received no financial support for the research, authorship, and/or publication of this article.

\section{Author's statement}

This report reflects the individual views of the authors and does not necessarily reflect the views of the MoH Turkey. 
Breastfeeding Promotion and Baby-Friendly Health Facilities in Turkey: A Systematic Approach to Scale up the Program

\section{References}

1. Section on Breastfeeding. Breastfeeding and the use of human milk. Pediatrics 2012; 129(3): e82741.

2. Lawrence RA. Breastfeeding-a public health issue, not just a matter of choice. Breastfeed Med 2012; 7(2): 67-8

3. Sankar MJ, Sinha B, Chowdhury R, et al. Optimal breastfeeding practices and infant and child mortality: a systematic review and meta-analysis. Acta Paediatr 2015; 104 (467):3-13.

4. Victora CG, Bahl R, Barros AJ, et al. Breastfeeding in the 21st century: epidemiology, mechanisms, and lifelong effect. Lancet 2016; 387 (10017): 475-90.

5. Innocenti declaration on the protection, promotion and support of breastfeeding. UNICEF, 1990. Available from: http://www.unicef.org/programme/breastfeeding/innocenti.htm. Accessed February 19, 2019.

6. Implementation guidance: protecting, promoting and supporting breastfeeding in facilities providing maternity and newborn services - the revised Baby-friendly Hospital Initiative. Geneva: World Health Organization; 2018.

7. International Code of Marketing of Breast-Milk Substitutes. Geneva: World Health Organization 1981. Available from: http://www.who.int/nutrition/publications/infantfeeding/9241541601/en/. Accessed February 19, 2019.

8. Global strategy for infant and young child feeding. Geneva: World Health Organization 2003. Available from: http://www.who.int/nutrition/publications/infantfeeding/9241562218/en/. Accessed February 19, 2019.

9. Infant and young child feeding. Model chapter for textbooks for medical students and allied health professionals. Geneva: World Health Organization 2009. Available from: http://www.who.int/maternal_child_adolescent/documents/9789241597494/en/. Accessed February 19, 2019.

10. Guideline: protecting, promoting and supporting breastfeeding in facilities providing maternity and newborn services. Geneva: World Health Organization; 2017.

11. Yalçın SS (editor). Dünyada ve Türkiye'de Bebek Dostu Girişimi. In: Emzirme Danışmanlığı Eğitimci Kitabı. Birinci baskı, Ankara: Sağlık Bakanlı̆̆ı; 2018:19-30.

12. Turkey Health Transformation Program Assessment Report 2003-2011. Ministry of Health of Turkey 2012. Available from: https://sbu.saglik.gov.tr/Ekutuphane/Yayin/452. Accessed February 19, 2019.

13. Health Statistics Yearbook 2016. Ankara: Ministry of Health 2017. Available from: https://dosyasb.saglik.gov.tr/Eklenti/1316o,sy2016enpdf.pdf?o. Accessed February 19, 2019.

14. Strategic Plan 2013-2017. Ankara: Ministry of Health of Turkey 2012. Available from: http://sbu.saglik.gov.tr/Ekutuphane/Yayin/454. Accessed February 19, 2019.

15. Marketing of breast-milk substitutes: national implementation of the international code, status report 2018. Geneva: World Health Organization; 2018.

16. Baby-Friendly Hospital Initiative. Revised, Updated and Expanded for Integrated Care, Section 5. External Assessment and Reassessment. Geneva: World Health Organization 2009.

17. Hacettepe University Institute of Population Studies. Turkey Demographic and Health Surveys; 1993, 1998, 2003, 2008, 2013. Available from: http://www.hips.hacettepe.edu.tr/eng/publicitions.shtml. Accessed February 19, 2019.

18. Baby-Friendly Hospital Initiative. Revised, Updated and Expanded for Integrated Care, Section 1. Background and Implementation. Geneva: World Health Organization 2009. Available from: http://www.who.int/nutrition/publications/infantfeeding/bfhi_trainingcourse/en/. Accessed February 19, 2019.

19. Semenic S, Childerhose JE, Lauzière J, Groleau D. Barriers, facilitators, and recommendations related to implementing the Baby-Friendly Initiative (BFI): an integrative review. J Hum Lact 2012; 28: 317-34.

20. Baby-Friendly Hospital Initiative. Revised, Updated and Expanded for Integrated Care, Section 3. Background and Implementation. Geneva: World Health Organization 2009. Available from: http://www.who.int/nutrition/publications/infantfeeding/bfhi_trainingcourse/en/. Accessed February 19, 2019.

21. Haddad L, Achadi E, Bendech MA, et al. Global Nutrition Report, Actions and Accountability to Accelerate the World's Progress on Nutrition. J Nutr 2015; 145: 663-71. 
Breastfeeding Promotion and Baby-Friendly Health Facilities in Turkey: A Systematic Approach to Scale up the Program

22. Rowe-Murray HJ, Fisher JR. Baby friendly hospital practices: cesarean section is a persistent barrier to early initiation of breastfeeding. Birth 2002; 29(2): 124-31.

23. Agostoni C, Decsi T, Fewtrell M, et al. Complementary feeding: a commentary by the ESPGHAN Committee on Nutrition. J Pediatr Gastroenterol and Nutr 2008; 46 (1): 99-110.

24. EFSA Panel on Dietetic Products, Nutrition and Allergies (NDA), Scientific Opinion on the appropriate age for introduction of complementary feeding of infants. EFSA Journal 2009; 7 (12): 1423 (38 pp.). Available from: http://onlinelibrary.wiley.com/doi/10.2903/j.efsa.2009.1423/epdf. Accessed February 19, 2019.

25. Fewtrell M, Bronsky J, Campoy C, et al. Complementary Feeding: A Position Paper by the European Society for Paediatric Gastroenterology, Hepatology, and Nutrition (ESPGHAN) Committee on Nutrition. J Pediatr Gastroenterol and Nutr 2017;64(1):119-32.

26. Bagci Bosi AT, Eriksen KG, Sobko T, Wijnhoven TM, Breda J. Breastfeeding practices and policies in WHO European Region Member States. Public Health Nutr 2016; 19(4): 753-64.

27. Pérez-Escamilla R, Martinez JL, Segura-Pérez S. Impact of the Baby-friendly Hospital Initiative on breastfeeding and child health outcomes: a systematic review. Matern Child Nutr 2016; 12(3): 402-17.

28. Saadeh RJ. The Baby-Friendly Hospital Initiative 20 years on: facts, progress, and the way forward. J Hum Lact 2012; 28(3): 272-5.

29. Bettinelli ME, Chapin EM, Cattaneo A. Establishing the Baby-Friendly Community Initiative in Italy: development, strategy, and implementation. J Hum Lact 2012; 28(3): 297-303.

30. Casanovas C, Saadeh R. Scaling up protection, promotion, and support of breastfeeding at the community level. Food Nutr Bull 2009; 30(2 Suppl): 230-5.

31. Sinha B, Chowdhury R, Sankar MJ, et al. Interventions to improve breastfeeding outcomes: a systematic review and meta-analysis. Acta Paediatr 2015; 104(467): 114-34. 